\title{
Dissimilatory sulfate reduction and methane production in Gotland Deep sediments (Baltic Sea) during a transition period from oxic to anoxic bottom water (1993-1996)
}

\author{
Levent Piker*, Rolf Schmaljohann, Johannes F. Imhoff**
}

Institut für Meereskunde, Abteilung für Marine Mikrobiologie, Düsternbrooker Weg 20, D-24105 Kiel, Germany

\begin{abstract}
During a transition period from oxic to anoxic conditions in the bottom water, rates of sulfate reduction and methane production, methane fluxes, as well as concentration profiles of sulfate, sulfide and methane were measured in sediments at a central site of the Gotland Deep (Stn AL 93, $241 \mathrm{~m}$ depth), which is regarded as representative for the deepest part of this basin. During this period from 1993 to 1996 oxic conditions in the bottom water prevailed from spring 1994 until summer 1995 with oxygen concentrations decreasing progressively with time. In the sediments methane production occurred primarily in layers below $1 \mathrm{~m}$ depth and flux rates of methane to the sediment surface were characterized by a steep concentration gradient from approx. $5 \mathrm{mM}$ at $4 \mathrm{~m}$ depth to values close to $30 \mu \mathrm{M}$ at the surface, determined by diffusion processes and anaerobic oxidation of methane. Both processes were independent of changes at the sediment surface. Differences in the flux rates of methane between the deeper part with a mean value of $259 \mu \mathrm{mol} \mathrm{m}^{-2} \mathrm{~d}^{-1}$ and the upper layers with a mean of $47.7 \mu \mathrm{mol} \mathrm{m} \mathrm{m}^{-2} \mathrm{~d}^{-1}$ indicate that a considerable proportion of the methane is oxidized within the anoxic horizon of the sediment ( 71 to $86 \%$ in the layer from 40 to $70 \mathrm{~cm}$ ). Low rates of methane production found within the top $20 \mathrm{~cm}$ of the sediment during periods of oxic bottom water increased after depletion of oxygen and resulted in a clear maximum of the methane concentration in the top $2 \mathrm{~cm}$. Sulfate concentrations declined exponentially from values of $11.5 \mathrm{mM}$ in June 1994 and $8.5 \mathrm{mM}$ in October 1995 at the sediment surface to values of $2.5 \mathrm{mM}$ at $20 \mathrm{~cm}$ depth and of less than $0.5 \mathrm{mM}$ at 50 to $60 \mathrm{~cm}$ depth. High sulfate reduction rates $\left(150\right.$ to $\left.250 \mathrm{nmol} \mathrm{cm}{ }^{-3} \mathrm{~d}^{-1}\right)$ in the upper part of the sediment $(8$ to $13 \mathrm{~cm}$ ) coincided with maxima of sulfide concentrations. During the time period of this investigation an increase of maximum sulfide concentrations in the sediment from 1 to $10 \mathrm{mM}$ was measured together with decreasing oxygen concentrations in the deep water. At the same time sulfate reduction established a small but distinct maximum at the top layer of the sediment $(0$ to $2 \mathrm{~cm})$. The relative importance of sulfate reduction and methanogenesis in the carbon budget of the Gotland Deep sediments is calculated on the basis of the actual measurements.
\end{abstract}

KEY WORDS: Sulfate reduction - Sulfide - Methane production - Methane fluxes $\cdot$ Gotland Deep · Baltic Sea

\section{INTRODUCTION}

The Gotland Deep is one of the major deep basins of the Baltic Sea. It is located within the Eastern Gotland Basin between the island of Gotland (Sweden) and

\footnotetext{
- Present address: Coastal Research and Management, Zum Tamberg 2, D-24247 Mielkendorf, Germany

- Addressee for correspondence.

E-mail: jimhoff@ifm.uni-kiel.de
}

Latvia, and has a maximum water depth of $241 \mathrm{~m}$. A permanent thermo-/halocline at 60 to $80 \mathrm{~m}$ water depth largely inhibits water exchange between surface water ( 7 to $8 \%$ salinity) and deep water ( 11 to $13 \%$ ). Long anoxic stagnation periods of the deep water were only interrupted by irregular, lateral intrusions of water masses from the North Sea with higher salinity and moderate oxygen content. The investigation period of this study (1993 to 1996) was preceded by an unusually long anoxic period from 1979 to 1993 and a massive 
salt water intrusion into the Baltic Sea starting in January 1993. During this anoxic time period stable gradients of sulfide and methane from the sediment to the chemocline at 120 to $130 \mathrm{~m}$ water depth were established in the water column. Maximum concentrations near the sediment surface were more than $150 \mu \mathrm{M}$ sulfide and $800 \mathrm{nM}$ methane (Brettar \& Rheinheimer 1991, Schmaljohann unpubl. results)

In the natural environment methanogenesis and sulfate reduction are competing processes in the anaerobic decomposition of organic matter. Competition is governed by the redox potential, the availability of electron acceptors and the affinity for common substrates such as acetate and hydrogen. Though methanogenesis is a dominant process in fresh water sediments, in the marine environment methanogenic bacteria are quite effectively outcompeted by sulfate reducers which are nearly unlimited by the availability of their common electron acceptor and have a greater affinity to hydrogen and acetate (Ward \& Winfrey 1985).

There is considerable information on the relevance of sulfate reduction and methanogenesis in marine and freshwater sediments (see reviews by Ward \& Winfrey 1985, Skyring 1987, Widdel 1988). Comparatively less is known about brackish water habitats, which exhibit intermediate salinities and sulfate concentrations compared to the 2 former types of ecosystems. Investigations have been largely restricted to shallow coastal areas and inlets (Iversen \& Blackburn 1981, Whiticar 1982, Heyer et al. 1990, Jørgensen et al. 1990, Schmaljohann 1996). First studies concerning rates of methanogenesis and sulfate reduction in sediments of deep brackish water bodies in the Baltic Sea were published by Lein et al. (1981) and Lein (1983).

This first salt water intrusion after 14 yr of permanent anoxic conditions in the bottom water of the Gotland Basin provided the opportunity to investigate the influence of oxic water on anaerobic processes (i.e. sulfide and methane production) in a generally anoxic sediment and the re-establishment of anoxic, sulfidic conditions. We quantified these processes in a sediment of the Gotland Deep, calculated their proportions in the anaerobic decomposition of organic matter, and determined changes on the sediment biogeochemistry during the transition period from oxic to anoxic conditions in the bottom water.

\section{MATERIALS AND METHODS}

Sampling. Samples were taken and measurements done during 7 expeditions to the Gotland Deep with the RV 'Alkor' (April 1993, June and August 1994, May and October 1995, May and October 1996) at Stn AL 93 $\left(57^{\circ} 18.51^{\prime} \mathrm{N}, 20^{\circ} 06.88^{\prime} \mathrm{E}\right)$ located in the deepest part of the Gotland Deep (241 m water depth). Sediment cores of up to $1 \mathrm{~m}$ length were obtained using a small gravity corer (Rumohr-Lot) fitted with liners $(7.4 \mathrm{~cm}$ inner diameter). Two undisturbed cores were used for electrode measurements and for concentration and rate measurements, respectively, in order to obtain sufficient sediment for the measurements and to minimize disturbance due to subsampling. A third core was taken to determine grain size, water content and organic matter. Data on concentrations and rates during June 1994, May 1995, October 1995 and October 1996 were determined in identical cores

Chemical analysis. Immediately after sampling $\mathrm{pH}$ and redox potential were measured simultaneously in the sediment cores using Pt electrodes with a small diameter (Mettler-Toledo, Steinbach) and a $\mathrm{pH} / \mathrm{mV}$ meter (WTW, Weilheim). Feeding of electrodes into the sediment was performed at steps of 0.5 or $1.0 \mathrm{~cm}$. Readings of redox and $\mathrm{pH}$ values were constant after 3 and $1 \mathrm{~min}$, respectively.

Grain size distribution was obtained by dry sieving using a standard series of sieves $(2000,1000,500,250$, $125,63 \mu \mathrm{m})$. Water content was measured by weight loss after drying at $75^{\circ} \mathrm{C}$ for $24 \mathrm{~h}$ (Holme \& McIntyre 1984) and organic matter was determined by weight loss of the dried sample after $6 \mathrm{~h}$ in a $550^{\circ} \mathrm{C}$ furnace (loss on ignition).

Pore water from sediments was recovered by centrifuging sediment slices for $10 \mathrm{~min}$ at $3500 \times g$ and $4^{\circ} \mathrm{C}$. In order to minimize loss of hydrogen sulfide the sediment was transferred rapidly to centrifuge tubes which were completely filled and sealed by gas-tight viton stoppers.

For determination of hydrogen sulfide an aliquot of pore water was fixed in $5 \%$ zinc acetate $(\mathrm{w} / \mathrm{v})$ immediately after centrifugation and determined according to Cline (1969)

Sulfate concentrations were measured using single column ion chromatography (modified after Gjerde et al. 1980) under isocratic conditions (eluent: $3 \mathrm{mM}$ phtalic acid, $\mathrm{pH} 4.9$; flow rate: $2 \mathrm{~cm}^{3} \mathrm{~min}^{-1}$; HPLC pumping system 420, Kontron, Milano). Anions were separated at $40^{\circ} \mathrm{C}$ on a silica-based column (Anion $\backslash S, 250 \times$ $4.6 \mathrm{~mm}$, Wescan, Deerfield). Pore water samples had to be diluted 1:20 in suprapure water (Milli-Q-UF-water system, Millipore) before injection (injection volume: $100 \mu$ l) to clearly resolve peaks of chloride and sulfate. Conductivity was used for detection and integration of the chromatograms was performed by PC-integration software (Kontron, Milano). Calibration curves showed linear correlation between $r^{2}=0.96$ and $r^{2}=0.98$

Methane concentrations in sediment samples were measured using a headspace technique salting out of the gas. Subcores $\left(5 \mathrm{~cm}^{3}\right)$ of each depth were taken with cut-off syringes. The syringe contents were injec- 
ted into $24 \mathrm{~cm}^{3}$ screw-cap vials containing $5 \mathrm{~cm}^{3}$ of distilled water and $3.0 \mathrm{~g}$ of sodium chloride. The vials were closed air-tight with screw caps containing butyl rubber septa. Following intensive shaking and at least $2 \mathrm{~h}$ of equilibration, samples of the headspace gas were injected into the sample loop of a gas chromatograph fitted with a flame ionization detector. Gases were separated on a $2 \mathrm{~m} \times 2 \mathrm{~mm}$ Hayesep T column with nitrogen at a flow rate of $20 \mathrm{~cm}^{3} \mathrm{~min}^{-1}$ as carrier gas and an oven temperature of $100^{\circ} \mathrm{C}$. Methane concentrations were corrected for water content of the sediment to give concentrations in the pore water.

Rates of dissimilatory sulfate reduction. Rates of dissimilatory sulfate reduction (DSR) were determined by incubating $5 \mathrm{~cm}$ long duplicate subcores with $185 \mathrm{kBq}$ vertically injected ${ }^{35} \mathrm{~S}$ sulfate (carrier-free, New England Nuclear). Three injections were done in a triangular arrangement into each subcore using a micromanipulator and a Hamilton syringe providing good horizontal and uniform vertical distribution of the tracer. After incubation for 6 to $8 \mathrm{~h}$ at in situ temperature $\left(5^{\circ} \mathrm{C}\right)$ sediment segments of 1 to $2.5 \mathrm{~cm}$ were removed to centrifuge tubes containing 2 to $5 \mathrm{~cm}^{3} 20 \%$ $\mathrm{Zn}$ acetate $(\mathrm{w} / \mathrm{v})$. The total reduced inorganic sulfur formed was distilled following the 1-step chromium and acid reduction procedure of Fossing \& Jørgensen (1989). Radioactivity of trapped hydrogen sulfide was measured in a liquid scintillation counter (1900 CA Tricarb, Packard). Sulfate reduction rates were calculated according to Jørgensen (1978).

Rates of methane production. Methane production rates were measured by determining the net increase of methane concentrations in the headspace of sediment suspensions. Sediment samples were diluted 1:1 with oxygen- and sulfate-free artificial seawater, and most of the methane was stripped off with $\mathrm{N}_{2}(15 \mathrm{~min}$ ). Aliquots of $5 \mathrm{~cm}^{3}$, in triplicate for each sediment depth, were filled into $13 \mathrm{~cm}^{3}$ crimp vials and sealed under $\mathrm{N}_{2}$. The vials were incubated under in situ temperature $\left(5^{\circ} \mathrm{C}\right)$ and in darkness for $10 \mathrm{~d}$, and the increase of methane in the headspace was measured by gas chromatography. Corrections were made for methane dissolved in the liquid phase at different partial pressures in the gas phase. Controls with an addition of $20 \mathrm{mM}$ 2-bromoethanesulfonate (BES), a specific inhibitor of methanogenesis, were made to discriminate between biological activity and desorption of methane from particles. Only the part of methane release which could be inhibited by this compound was considered for the calculations.

Calculation of diffusive methane fluxes and sulfate reduction rates. The diffusive flux of methane was calculated for deep sediment layers between 60 and $90 \mathrm{~cm}$, and for sulfate-rich subsurface layers between 22.5 and $1 \mathrm{~cm}$ depth. The difference of both flux rates was used to estimate the rate of anaerobic methane oxidation and the percentage of the upward diffusing methane consumed by this process. Flux rates were calculated from the vertical profile of pore water methane concentrations using Fick's first law:

$$
J_{\mathrm{D}}=-\phi D_{\mathrm{Sed}}(\mathrm{d} C / \mathrm{d} z)
$$

where $J_{D}$ is the diffusive flux $\left(\mu \mathrm{mol} \mathrm{CH}_{A} \mathrm{~m}^{-2} \mathrm{~d}^{-1}\right)$; $\phi$ is the porosity of the sediment; $D_{\text {Sed }}$ is the sediment diffusion coefficient, calculated from the molar diffusion coefficient $(D)$ by the empirical equation $D_{\text {Sed }}=D \phi^{2}$ (Lerman 1979) using the $5^{\circ} \mathrm{C}$ value for $D(0.87 \times$ $10^{-5} \mathrm{~cm}^{-2} \mathrm{~s}^{-1}$ ) in Sahores \& Witherspoon (1970); and $\mathrm{dC} / \mathrm{d} z$ is the measured methane concentration gradient in the considered sediment layer $\left(\mu \mathrm{mol} \mathrm{dm} \mathrm{dm}^{-3} \mathrm{~cm}^{-1}\right)$.

Sulfate reduction rates (SRR) were calculated using the theoretical model of Berner (1964), which describes the concentration changes of sulfate with time in a given depth below the sediment surface as a function of diffusion processes, sediment accumulation, and DSR. In order to derive the depth-dependent rate of sulfate reduction a diffusion coefficient for sulfate of $D_{\mathrm{S}}=0.46 \times 10^{-5} \mathrm{~cm}^{-2} \mathrm{~s}^{-1}\left(4^{\circ} \mathrm{C}, \phi=0.90\right.$; Iversen \& Jørgensen 1985), a sedimentation rate in the Gotland Deep of $1 \mathrm{~mm} \mathrm{yr}^{-1}$ (Niemestö \& Voipio 1974), and the corresponding exponential function of the sulfate gradient in the sediment were used.

\section{RESULTS}

\section{General observations}

While oxygen transported into the deep water of the Gotland Basin by the first significant inflow in 1993 was consumed within a rather short time, further intrusions of oxic water in December 1993 and March 1994 resulted in a complete removal of sulfide from the water and a completely oxic water column during 1994 and the first half of 1995. Oxygen concentrations in the deep water reached values as high as $4.3 \mathrm{mg} \mathrm{dm}^{-3}$ (Nehring et al. 1995, K. Gocke, Kiel, pers. comm.). During 1995 oxygen in the deep water was depleted again, and in October 1995 low concentrations of sulfide were present in the water layer up to $2 \mathrm{~m}$ above the bottom (Fig. 1). A minor inflow in May 1996 again supplied low amounts of oxygen to the deep water which were consumed rapidly, however, allowing methane and sulfide to penetrate into the water column up to $215 \mathrm{~m}$ depth in October 1996.

An optical documentation of the sediment surface of the Gotland Deep by underwater video during the period of oxic bottom water (in June 1994 and May 1995) revealed white or yellowish bacterial mats on its surface. These bacterial mats contained filamentous 


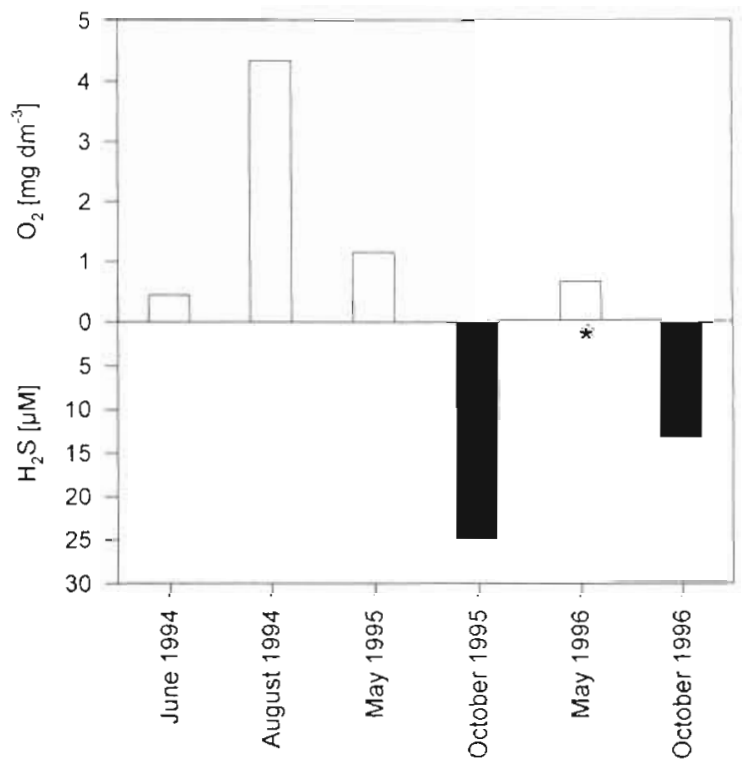

Fig. 1. Concentrations of $\mathrm{O}_{2}$ (white bars) and $\mathrm{H}_{2} \mathrm{~S}$ (black bars) during the study period in the bottom water $2 \mathrm{~m}$ above the sediment surface. Missing bars represent zero concentrations except $\star \mathrm{H}_{2} \mathrm{~S}$ not determined

sulfur-oxidizing bacteria resembling Beggiatoa species. During 1994 and early 1995 numerous individuals of $H$. sarsi (Polychaeta) were also present on the sediment surface. The bacterial mats disappeared and Harmothoë died off when conditions in the bottom water close to the sediment surface became anoxic (October 1995). No macrofauna and no tubes indicating bioturbation were observed within the sediments. The lack of bioturbation resulted in a fine layering of the sediment in the deep part of the Gotland basin over very long time periods, as could be seen in sediment cores down to $4 \mathrm{~m}$ depth (data not shown).

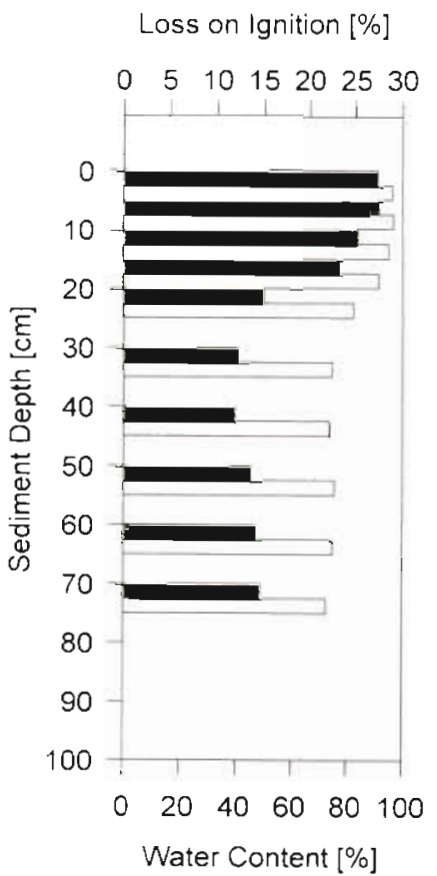

Fig. 2. Water content (white bars) and content of organic matter (loss on ignition; black bars) of the sediment at Stn AL 93

\section{Characterization of the sediment at Stn AL 93}

Sediments consisted of fine silty material without sandy components. The material of the top 15 to $20 \mathrm{~cm}$ was of brownish fluffy consistency followed by mushy black fine silt down to $35 \mathrm{~cm}$ depth and a dark greyish zone between 35 to $60 \mathrm{~cm}$ that merged to a black-ribboned sediment further down. The water content of more than $90 \%(\mathrm{w} / \mathrm{v})$ in the first $20 \mathrm{~cm}$ decreased to $75 \%$ from 20 to $30 \mathrm{~cm}$ and did not change significantly in deeper layers (Fig. 2). The content of organic matter, determined as loss on ignition, was between 23 and $27 \%$ within the first $20 \mathrm{~cm}$ at all sampling dates, decreasing to 12 to $14 \%$ in deeper layers (Fig. 2).
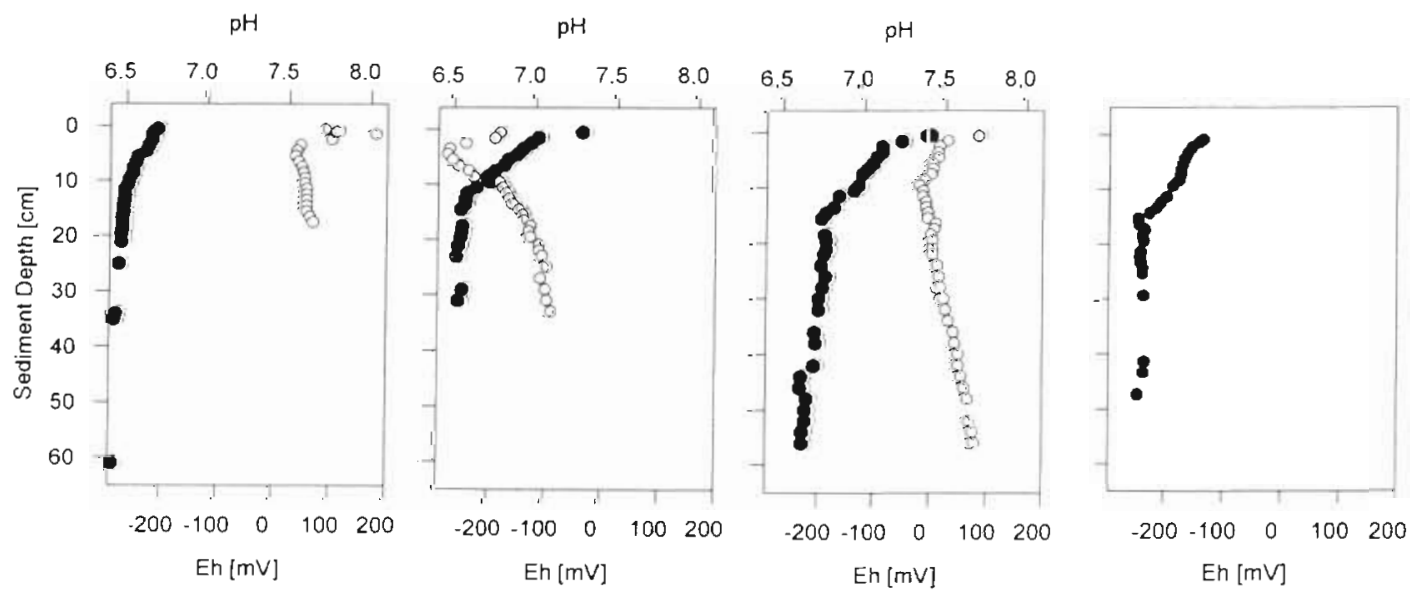

Fig. 3. Redox potential (-) and $\mathrm{pH}(0)$ as vertical depth profiles in sediment of Stn AL 93 (from left to right) in June 1994, May 1995, October 1995, and October 1996 ( $\mathrm{pH}$ not determined) 


\section{Redox potential and $\mathrm{pH}$}

A relatively constant negative redox potential in the vertical profile was observed in June 1994, with low Eh values of $-200 \mathrm{mV}$ at the sediment surface decreasing to $-295 \mathrm{mV}$ at $60 \mathrm{~cm}$ depth (Fig. 3). During the following cruises the redox potential in the uppermost centimeter increased to 0 and $+30 \mathrm{mV}$ in May and October 1995, respectively, before it decreased again to $-120 \mathrm{mV}$ in May 1996. At these sampling dates the redox potential decreased to values between -200 and $-250 \mathrm{mV}$ with depth. A high oxidation state of the sediment at 10 to $15 \mathrm{~cm}$ depth was still recorded in October 1996, when reducing conditions were already re-established at the sediment surface. The vertical profile of the $\mathrm{pH}$ showed a minimum in the sediment layer from 6 to $10 \mathrm{~cm}$, a few centimeters above maxima of SRR and sulfide concentrations, and was most pronounced in May 1995 but slowly disappeared later (Fig. 3).

\section{Concentrations of sulfate and sulfide and rates of dissimilatory sulfate reduction}

Sulfate concentrations decreased exponentially with sediment depth. The steepest decline was always observed between 10 and $15 \mathrm{~cm}$. At depths of 20 and $60 \mathrm{~cm}$ concentrations were quite constant, approximately 2.5 and $0.5 \mathrm{mM}$ respectively, at all sampling dates. During the study period sulfate concentrations in the top $2 \mathrm{~cm}$ decreased from 11.5 to $8.5 \mathrm{mM}$ indicating a net sulfate consumption by highly active sulfate reduction in this layer. Apparently, sulfate that had penetrated into the sediment down to 2 to $4 \mathrm{~cm}$ during the period of high oxygen concentrations in the bottom water and negligible sulfate reduction in the top sediment layer was consumed much more slowly causing a sulfate maximum at 2 to $4 \mathrm{~cm}$ depth in October 1995 and October 1996.

The sulfide concentration always had maxima at 10 to $20 \mathrm{~cm}$ (Fig. 4). In October 1995 and October 1996 an additional maximum developed at 0 to $2 \mathrm{~cm}$, which at both sampling dates coincided with lower sulfate concentrations beneath the sediment surface (Fig. 4). The deeper as well as the near-surface sediment horizons with maxima of sulfide concentrations were also characterized by maxima of sulfate reduction (see Fig. 5). A double peak of sulfide concentrations was characteristic for this sediment and was observed repeatedly between 10 and $20 \mathrm{~cm}$ (e.g. June 1994 and October 1995). Maxima of sulfide concentrations increased from about $1 \mathrm{mM}$ (June 1994 and May 1995) to approximately $3 \mathrm{mM}$ (October 1995), to more than $7 \mathrm{mM}$ (May 1996, data not shown) and $10 \mathrm{mM}$ (October 1996)

SRR at Stn AL 93 revealed similar distribution patterns at different sampling dates (Fig. 5) with maximal
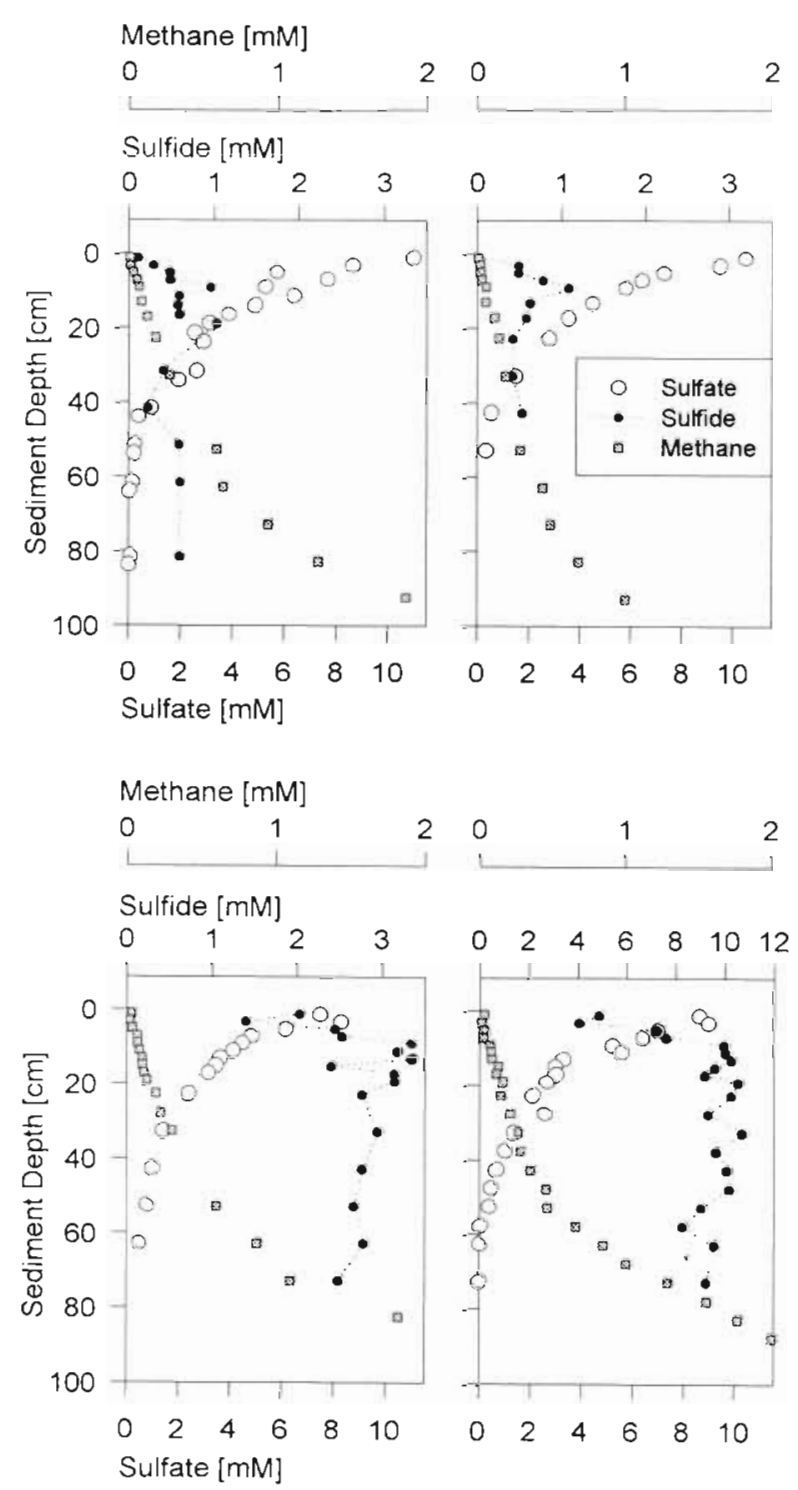

Fig. 4. Concentrations of sulfide, sulfate and methane as sediment vertical profiles at Stn AL 93 in June 1994 (top left), May 1995 (top right), October 1995 (bottom left), and October 1996 (bottom right; please note the different scale of sulfide concentration)

rates of 150 to $250 \mathrm{nmol} \mathrm{cm}^{-3} \mathrm{~d}^{-1}$ at a depth of 8 to $13 \mathrm{~cm}$ while SRR in adjacent layers did not exceed $50 \mathrm{nmol} \mathrm{cm} \mathrm{cm}^{-3} \mathrm{~d}^{-1}$. In May and October 1995 the development of a second maximum between 0 and $2.5 \mathrm{~cm}$ depth was observed, although at that time this sediment layer did not show a pronounced negative redox potential. Integrated SRR for the upper $20 \mathrm{~cm}$ based on ${ }^{35} \mathrm{~S}$-sulfate measurements were 3.8 (June 1994), 7.6 (May 1995) and 7.2 (October 1995) $\mathrm{mmol} \mathrm{m}^{-2} \mathrm{~d}^{-1}$, whereas the calculation using Berner's diffusion model (Berner 1964) led to corresponding values of $0.9,1.8$

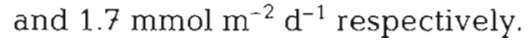



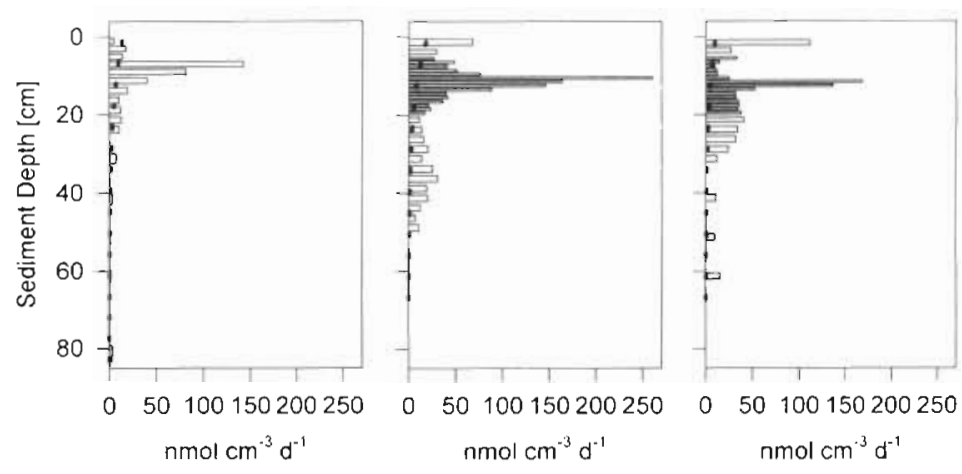

Fig. 5. Depth distribution of sulfate reduction rates (mean of duplicates) at Stn AL 93 in June 1994 (left), May 1995 (middle), and October 1995 (right). The thickness of the bars is adapted to the sampled sediment horizon (space between bars: not determined). Calculated SRR (sulfate reduction rates) using Berner's diffusion model are depicted as dotted lines

\section{Methane production and methane concentrations}

Methane concentrations steadily increased from the surface to a depth of at least $80 \mathrm{~cm}$, where values between 0.7 and $1.8 \mathrm{mM}$ were found (Fig. 4). Saturation concentrations were not reached at that depth and there was no indication of in situ formation of gas bubbles. In one instance it was possible to obtain a sediment sample from the end of a $4 \mathrm{~m}$ long 'Kastenlot' corer, which had a methane content of $5.1 \mathrm{mM}$. The increase of methane concentrations was nearly linear from the sediment surface to a depth of about $50 \mathrm{~cm}$ and became exponential below that depth. The transition between these different curve sections of the methane profile corresponded to sulfate concentrations in the sediment of about $1 \mathrm{mM}$.

During periods with oxic bottom water (spring 1994 to summer 1995) a continuous gradient with decreasing methane concentrations towards the surface

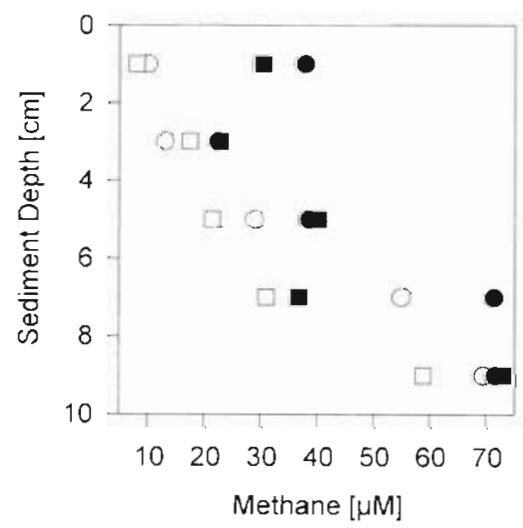

Fig. 6. Methane concentration profiles in the upper $10 \mathrm{~cm}$ sediment of Stn AL 93 in June 1994 (O), May 1995 (ㅁ), October 1995 (-), and October 1996 ( existed with concentrations as low as 8 to $10 \mu \mathrm{M}$ in the pore water of the top layer $(0$ to $2 \mathrm{~cm}$; Fig. 6). During anoxic periods (October 1995 and later), with active methane formation but in the absence of aerobic methane oxidation at the sediment surface, methane concentrations were higher in the 0 to $2 \mathrm{~cm}$ layer ( 30 to $34 \mu \mathrm{M}$ ) than at 2 to $4 \mathrm{~cm}$ depth.

The fact that methane concentrations increased without any evidence of saturation to sediment depths of at least 80 to $90 \mathrm{~cm}$ is an indication that the main methane production occurred below that depth. As it was not possible with the available sampling gear to obtain sediment samples of depths of more than $1 m_{1}$ an estimation of the rate of methanogenesis was carried out by calculation of the methane flux rate in layers between 62.5 and $92.5 \mathrm{~cm}$. The methane flux rates varied between 146 and $396 \mu \mathrm{mol} \mathrm{m} \mathrm{m}^{-2} \mathrm{~d}^{-1}$ with a mean value of $259 \mu \mathrm{mol} \mathrm{m}{ }^{-2} \mathrm{~d}^{-1}$ compared to 42 to $55 \mu \mathrm{mol} \mathrm{m} \mathrm{m}^{-2} \mathrm{~d}^{-1}$ (mean value: $47.7 \mu \mathrm{mol} \mathrm{m} \mathrm{m}^{-2} \mathrm{~d}^{-1}$ ) in the near-surface, linear region of the methane profile (Table 1 ).

Though the bulk of methane was produced below the sulfate-containing sediment layers, low rates of methanogenesis could also be measured close to the sediment surface in the presence of sulfate. In sediment suspensions incubated under in situ temperature and without additional substrates, a net methane production was determined within the upper $20 \mathrm{~cm}$ of sediment, while only negligible activity was recorded between 20 and $80 \mathrm{~cm}$ depth (Fig. 7). During the period with oxic bottom water in June 1994, a small maximum of activity was found between 10 and $15 \mathrm{~cm}$ depth. This maximum was replaced by strongly increased activity close to the sediment surface in the sediment during May and October 1995 (Fig. 7). In October 1995 and October 1996 small maxima of methane concentrations were also found at 0 to $2 \mathrm{~cm}$ depth (Fig. 6). Integrated methane production rates in the upper $20 \mathrm{~cm}$ increased from $3.3 \mu \mathrm{mol} \mathrm{m} \mathrm{m}^{-2} \mathrm{~d}^{-1}$ in June 1994 to values of $4.2 \mu \mathrm{mol} \mathrm{m} \mathrm{m}^{-2} \mathrm{~d}^{-1}$ in August 1994, $8.6 \mu \mathrm{mol} \mathrm{m} \mathrm{m}^{-2}$ $\mathrm{d}^{-1}$ in May 1995, and $27.9 \mu \mathrm{mol} \mathrm{m} \mathrm{m}^{-2} \mathrm{~d}^{-1}$ in May 1996

\section{DISCUSSION}

The sediments of the Central Gotland Basin are a location of intensive anaerobic degradation of organic matter and are subjected to repeated changes from oxic to anoxic conditions at the sediment surface due to irregular inflow events. We were the first to have the opportunity to measure the significant changes that occurred in the sediment during a transition period from oxic to anoxic bottom water, the first such event 
Table 1. Methane flux rates and calculated anaerobic methane oxidation in the sediment of Stn AL 93 in the Gotland Deep

\begin{tabular}{|c|c|c|c|c|}
\hline Date & 16 June 1994 & 27 April 1995 & 5 October 1995 & 12 October 1996 \\
\hline Sediment horizon (cm) & $22.5-1.0$ & $22.5-1.0$ & $22.5-1.0$ & $22.5-1.0$ \\
\hline Porosity (average) & 0.973 & 0.954 & 0.970 & 0.983 \\
\hline Max. methane conc. ( $\mu \mathrm{M})$ & 182.0 & 147.2 & 197.7 & 153.4 \\
\hline Min. methane conc. $(\mu \mathrm{M})$ & 10.0 & 8.0 & 34.4 & 30.0 \\
\hline Methane flux rate $\left(\mu \mathrm{mol} \mathrm{m} \mathrm{m}^{-2} \mathrm{~d}^{-1}\right)$ & 55.4 & 42.3 & 52.1 & 41.0 \\
\hline Sediment horizon $(\mathrm{cm})$ & $92.5-62.5$ & $92.5-72.5$ & $82.5-72.5$ & $87.5-62.5$ \\
\hline Porosity (average) & 0.899 & 0.913 & 0.913 & 0.920 \\
\hline Max methane conc. $(\mu \mathrm{M})$ & 1863 & 1008 & 1868 & 2012 \\
\hline Min. methane conc. $(\mu \mathrm{M})$ & 634.6 & 498.3 & 1175.0 & 857.4 \\
\hline Methane flux rate $\left(\mu \mathrm{mol} \mathrm{m}^{-2} \mathrm{~d}^{-1}\right)$ & 223.6 & 145.8 & 396.4 & 270.1 \\
\hline Anaerobic methane oxidation rate $\left(\mu \mathrm{mol} \mathrm{m}^{-2} \mathrm{~d}^{-1}\right)$ & 168.2 & 103.5 & 344.3 & 229.1 \\
\hline Percentage of anaerobic methane oxidation $(\%)$ & 75.2 & 71.0 & 86.9 & 84.8 \\
\hline
\end{tabular}

after more than 14 yr. Changes in the sediments were demonstrated on the basis of (1) elevated sulfide and methane concentrations as indicators of terminal oxidation of organic carbon by DSR and methanogenesis, and (2) direct measurements of SRR and methane production rates. It became obvious that the hydrographic conditions of the bottom water had considerable impact on the biogeochemistry of the surface layers of the investigated sediments.

Stn AL 93 is representative of the central part of the Gotland Deep, where sedimentation rates were reported to be of the

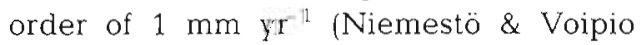
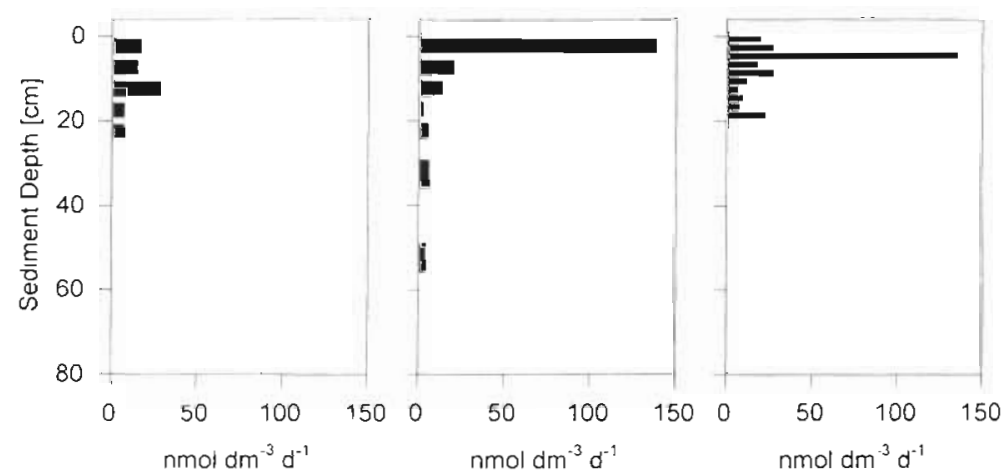

Fig. 7. Sediment vertical profile of methane production rates at Stn AL 93 in June 1994 (left), May 1995 (middle), and October 1995 (right; space between bars: not determined)

1974). Echosounding profiles through the Gotland Deep showed that at Stn AL 93 the thickness of the post-Ancylus deposits was considerably higher than at shallower stations, which indicates a higher sedimentation rate during the past $7000 \mathrm{yr}$ (Schmaljohann et al. 1998). This corresponds to higher amounts of organic matter (loss on ignition), sulfide and methane in the sediment as well as higher SRR and a much more pronounced decrease of sulfate concentrations with sediment depth (data not shown).

During the whole period of these investigations the sediment at Stn AL 93 and in its close vicinity appeared quite homogeneous and gave no indication of smallscale variations in structure and function. The comparison of different cores during each sampling period revealed similar sequence and thickness of the sediment layers and parallel measurements of the redox potential and pH in several cores during June 1994 and October 1995 confirmed shape and absolute values of the vertical profiles. A detailed analysis of the horizontal distribution of sulfide and methane in the deep part of the Gotland Basin around Stn AL 93 revealed a simultaneous increase of both concentrations during
1996 (Schmaljohann et al. 1998). On the basis of these observations and because of the sequential appearance of the changes it is quite conclusive that our data reflect time dependent changes rather than spatial heterogeneity.

\section{Re-establishment of anoxic conditions}

The comparatively high redox potential and steep redox gradient in May and October 1995 in the upper $15 \mathrm{~cm}$ of the sediment suggest a transition to suboxic conditions in the subsurface sediment due to the prolonged exposure to oxygen-containing bottom water. Apparently, oxidation processes in the sediment followed the establishment of oxic or anoxic conditions at the sediment surface after a considerable delay. This may be concluded from the low redox potential in the upper $15 \mathrm{~cm}$ in June 1994 when oxic bottom water was already in close contact with the sediment for more than a year and vice versa from the relatively 
high redox potential when oxygen in the bottom water was consumed already, as in October 1995 and 1996. The transition from oxic to anoxic conditions in the bottom water was accompanied by (1) a drop of the redox potential in the top layer of the sediment, (2) an increase of sulfide concentrations in the pore water and (3) a temporary increase of integrated SRR. Furthermore, at the sediment surface a zone of active methane production was newly established and led to increased methane concentrations in the top layer of the sediment.

\section{Sulfide}

Sulfide accumulated from maximum concentrations of $1 \mathrm{mM}$ in 1994 to $10 \mathrm{mM}$ in October 1996. Parallel measurements at several stations in the deep central part of the Gotland Basin demonstrated an increase of sulfide concentrations over the time, which was most evident during 1996 (Schmaljohann et al. 1998). The mechanism for the significant increases also in the deeper layers of the sediment down to $80 \mathrm{~cm}$ remains unclear. Because of the lack of bioturbation, one would assume that diffusion processes dominate in the investigated system. However, considering theoretical aspects of diffusion in marine sediments (Duursma \& Hoede 1967), the distance of sulfide diffusion from the main source of sulfide (peak of SRR at 8 to $13 \mathrm{~cm}$ sediment depth) is expected to lie in a range between 3 and $5 \mathrm{~cm} \mathrm{yr}^{-1}$. Therefore the increase of sulfide concentration in deeper sediment layers may be explained by increased sulfide production and decreased consumption, rather than by transport processes. Indeed, between June 1994 and May 1995 there was an average increase of SRR from 5 to

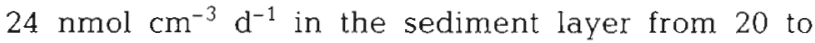
$80 \mathrm{~cm}$, which would be sufficient to explain an increase of the sulfide concentration of $7 \mathrm{mM}$ during a year, if there is no consumption or loss. In view of the low sulfate concentrations, it is unlikely, however, that reduction of sulfate alone was responsible for such an increase. High concentrations of elemental sulfur at this station with maximal concentrations up to $7 \mathrm{mM}$ and values of $2 \mathrm{mM}$ down to $60 \mathrm{~cm}$ depth during June 1994 and May 1995 (Schneider \& Imhoff 1996) would provide an alternative source for sulfide, though at present we have no indication for reduction of elemental sulfur in these horizons. It remains an open question how SRR in the deep layers can be influenced by processes at the sediment surface.

An important factor regulating the concentrations of free sulfide in the pore water of Baltic Sea sediments is the iron concentration, which is the limiting factor for the precipitation of sulfide as iron sulfide in Gotland
Deep sediments (Boesen \& Postma 1988). Therefore, the produced sulfide is supplied to the pool of free sulfide and causes immediate changes of the concentrations of free sulfide concentrations.

\section{Rates of dissimilatory sulfate reduction}

SRR at Stn AL 93 lie in the range of SRR in shallower parts of the Baltic and the North Sea (Limfjord: Jørgensen 1977; Limfjord, Aarhus Bay, Kysingfjord: ThodeAndersen \& Jørgensen 1989; southwestern Baltic coast: Piker \& Reichardt 1997) and exceed SRR in sediments of the Kattegat and the Belt Sea (Jørgensen \& Revsbech 1989, Jørgensen \& Bak 1991) by an order of magnitude. Repeatedly observed maxima of SRR in a sediment layer between 7 and $13 \mathrm{~cm}$ coincided with maxima of sulfide concentrations. However, neither the redox potential nor the sulfate concentration, the measured regulating factors of DSR, corresponded to these distribution patterns. Apparently, the redox potential as rate controlling factor involved in the regulation of DSR had largely been replaced by other environmental variables. This became most evident when a second SRR maximum could be detected in the upper sediment layer at relatively high redox potential. Concentrations of low-molecular-weight fatty acids (as preferred carbon sources for SRB) in the pore water also showed no striking coherence with SRR maxima. However, concentrations of dissolved free amino acids showed a negative correlation to these distribution patterns indicating a possible role as precursors of lowmolecular-weight fatty acids (Piker 1995)

Integrated SRR ( 0 to $20 \mathrm{~cm}$ sediment depth) were in the same order of magnitude as SRR at a comparable station in the Gotland Basin investigated earlier (4.85 $\mathrm{mmol} \mathrm{m} \mathrm{m}^{-2} \mathrm{~d}^{-1}$; recalculated from $\mu \mathrm{g} \mathrm{S} \mathrm{kg}{ }^{-1}$ dry weight, sum of integrated rates in sediment depths of 0 to 7 and 25 to $40 \mathrm{~cm}$; Lein et al. 1982). Lein (1983) inferred from low SRR at a sediment depth of 0 to $7 \mathrm{~cm}$ that the main activity of anaerobic microorganisms must be in deeper regions of stable anoxic conditions. He found maximal SRR at a depth of 25 to $40 \mathrm{~cm}$ but did not analyze the sediment layer at 7 to $13 \mathrm{~cm}$ where maxima of SRR were found in this study. This view is in contrast to our findings of elevated SRR in the upper $2.5 \mathrm{~cm}$ sediment depth in May and October 1995, where rather suboxic conditions were present 10 to $-100 \mathrm{mV}$ ). Apparently, sulfate reduction in the top sediment layer was inhibited by oxygen only in the first period with high concentrations of oxygen in the bottom water. However, with decreasing concentrations of oxygen in the bottom water, sulfate reduction activity in the subsurface layer increased as soon as oxygen content in the water phase was low. This led to the 
establishment of a second maximum of SRR in the uppermost sediment layer in May 1995, a time when oxygen was still present in the bottom water. It even appears that the oxic period in the top sediment layer stimulated sulfate reduction rates after oxygen concentrations were reduced.

In several studies with shelf and open ocean sediments the model of Berner (1964) described the decomposition of organic matter by DSR quite well (Westrich $\&$ Berner 1984). An assumption of this model is that sulfate-reducing bacteria oxidize organic matter according to first-order kinetics. Furthermore, the application of the model requires that the sediment system is in steady state, which means that diffusion coefficient, rate of sedimentation and depth-dependent rates of sulfate reduction are independent of time. It could not describe the situation we found in Gotland Deep sediments (broken line in Fig. 5). Applied to these sediments, the model underestimates the SRR approx. 4- to 5 -fold compared to the measured values. The observed deviation from the model indicates a dynamic rather than a steady-state situation in the investigated sediment, which could be seen in the development of concentration profiles of sulfate, sulfide and methane.

\section{Methane}

By comparing the methane flux rates in the near-surface region and in the zone of steep increase in the sulfate-free layers (Table 1) a remarkable difference can be noticed between Stn AL 93 and offshore marine sediments with oxic conditions in the overlying water column (e.g. Kattegat and Skagerrak: Iversen \& Jørgensen 1985; or the Santa Barbara Basin: Kosiur \& Warford 1979). In the Gotland Deep sediment there is a widely linear increase in methane from the surface to a depth of about $50 \mathrm{~cm}$, gradually changing into an exponential increase below that depth; the other offshore marine sediments show constant low or only threshold concentrations with no discernible gradient from the surface to the depth of sulfate depletion and a steep increase below. This difference can be quantified by calculating the methane flow rates in the nearsurface horizons and in the zone of steep increase in the sulfate-free layers (Table 1). At Stn AL 93 the difference in the flux rates of the 2 layers, representing the proportion of anaerobically oxidized methane, is lower ( 71 to $86 \%$; Table 1 ) than in other investigated marine sediments, resulting in a comparatively higher methane flux to the surface. Data reported for anaerobic consumption of methane in other marine sediments range between 90 and $100 \%$ of the upward diffusing methane (Reeburgh 1980, Devol 1983, Iversen \& Jørgensen 1985, Reeburgh \& Heggie 1977).
Methane gradients extending to the sediment surface were found in some permanently anoxic marine basins, such as the Black Sea (Reeburgh et al. 1991), and in very productive coastal sedimcnts, where methane production occurs close to the sediment surface, as in Saanich Inlet (Kuivila et al. 1990), Cape Lookout Bight (Hoehler et al. 1994) or in Kiel Harbour (Schmaljohann 1996).

\section{Methane production rates}

The experimentally determined methane production rates of the upper $20 \mathrm{~cm}$ of the sediment are within the range found in offshore marine sediments of the Black Sea (Heyer 1990), Bering Sea (Griffiths et al. 1982) or open Baltic Sea (Lein et al. 1981). They also fit very well to the data obtained by Lein et al. (1981) in the Gotland Deep (Stn 2622) with the radiotracer method (reduction of ${ }^{14} \mathrm{CO}_{2}$ ). These authors determined a rate of methanogenesis of $5.4 \mu \mathrm{mol} \mathrm{m}{ }^{-2} \mathrm{~d}^{-1}$ within the top $15 \mathrm{~cm}$ (recalculated after the given data), which is in the range of rates in our study ( 3.0 to $\left.8.5 \mu \mathrm{mol} \mathrm{m} \mathrm{m}^{-2} \mathrm{~d}^{-1}\right)$. Coastal shallow brackish water sediments in the southern part of the Baltic Sea showed rates which range between 553 and $2016 \mu \mathrm{mol} \mathrm{m} \mathrm{m}^{-2} \mathrm{~d}^{-1}$ for open areas and $1.1 \times 10^{5} \mu \mathrm{mol}$ $\mathrm{m}^{-2} \mathrm{~d}^{-1}$ for creeks and basins (Heyer et al. 1990). In Kiel Harbour, another site in the western part of the Baltic Sea with salinities of 15 to $22 \%$, methane production rates in the sediments seasonally varied between 302 and $1963 \mu \mathrm{mol} \mathrm{m} \mathrm{m}^{-2} \mathrm{~d}^{-1}$. The fact that only negligible net production was detected by the applied headspace method at depths below $25 \mathrm{~cm}$ could be due to the fact that anaerobic methane oxidation consumed the produced methane. As discussed above on the basis of the methane concentration profiles this process is expected to occur in the depth range in question. However, Lein et al. (1981), applying the tracer method for measuring methanogenesis in Gotland Basin sediments of different depths, also found no or only minimum activity below the surface maximum and increasing activity at depths of $85 \mathrm{~cm}$ or more. In comparison with methane flux rates in the surface layers (Table 1 ), the integrated in situ methane production ( 0 to $20 \mathrm{~cm}$ ) contributed 6 to $20 \%$ to the surface methane flux and may considerably influence the diffusion from the sediment to the water column during anoxic periods. The inverted methane gradients in the surface layers (Fig. 6) are indirect evidence of methane formation in the top sediment layer during anoxic periods. Though methane production at the sediment surface was superimposed by high vertical diffusion from deeper layers, production of methane and lack of aerobic methane oxidation during the anoxic period resulted in a 3 -fold increase of concentrations in the 0 to $2 \mathrm{~cm}$ layer and a relative increase compared to the 2 to $4 \mathrm{~cm}$ layer. 
Importance of sulfate reduction and methane production in the carbon budget of the Gotland Deep

The carbon consumption during sulfate reduction and methanogenesis can be calculated according to Ingvorsen \& Brock (1982) based upon the consumption of 2 mol organic matter $\left(\mathrm{CH}_{2} \mathrm{O}\right)$, corresponding to $24 \mathrm{~g}$ C, per mol $\mathrm{H}_{2} \mathrm{~S}$ and $\mathrm{CH}_{4}$ produced:

\section{Oxidation half reaction:}

Oxidation of organic matter:

$2\left(\mathrm{CH}_{2} \mathrm{O}\right)+2 \mathrm{H}_{2} \mathrm{O} \rightarrow 2 \mathrm{CO}_{2}+8 \mathrm{e}^{-}+8 \mathrm{H}^{+}$

Reduction half reaction:

Sulfate reduction: $\mathrm{SO}_{4}^{2-}+8 \mathrm{e}^{-}+9 \mathrm{H}^{+} \rightarrow \mathrm{HS}^{-}+4 \mathrm{H}_{2} \mathrm{O}$

Methane formation: $\mathrm{CO}_{2}+8 \mathrm{e}^{-}+8 \mathrm{H}^{+} \rightarrow \mathrm{CH}_{4}+2 \mathrm{H}_{2} \mathrm{O}$

Based on an average SRR of about $6 \mathrm{mmol} \mathrm{m} \mathrm{m}^{-2} \mathrm{~d}^{-1}$ (in the upper $20 \mathrm{~cm}$ of Stn AL 93 in June 1994, May and October 1995) the annual oxidized organic carbon by DSR amounts to $52.5 \mathrm{~g} \mathrm{C} \mathrm{m}^{-2} \mathrm{yr}^{-1}$. This is $44 \%$ of the total average primary production in the Central Baltic (120 g C m${ }^{-2} \mathrm{yr}^{-1}$; Gocke 1996). As Stn AL 93 is representative of only the deepest part of the Gotland Basin, this calculation is valid only for this part and would overestimate the average annual oxidized organic carbon by DSR, if applied to the whole basin.

On average methane production rates in the deeper sediment layers (>80 cm depth) were $259 \mu \mathrm{mol} \mathrm{m}{ }^{-2} \mathrm{~d}^{-1}$ (Table 1), corresponding to $2.7 \mathrm{~g} \mathrm{C} \mathrm{m}^{-2} \mathrm{yr}^{-1}$ and integrated rates of methane production in the sulfate-containing, surface layers ( 0 to $20 \mathrm{~cm}$ depth) were $5.8 \mu \mathrm{mol}$ $\mathrm{m}^{-2} \mathrm{~d}^{-1}$ (corresponding to $0.05 \mathrm{~g} \mathrm{C} \mathrm{m}^{-2} \mathrm{yr}^{-1}$ ). These calculations show that methanogenesis is not important in the main sulfate reduction layer, where the percentage of carbon consumption is only $0.1 \%$ of that consumed by DSR. Including the deeper layer this proportion rises to $4.6 \%$

Acknowledgements. The authors thank the masters and crews of the RV 'Alkor' for their cooperation and professional help in mud sampling, $\mathrm{C}$. Hiegel for her assistance in the ${ }^{35} \mathrm{~S}$ distillation, and $M$. Drews who kindly provided us with the latest sulfate data from October 1996 completing our data set. This work was supported by Grant No. 03F0123 from the Federal Ministry of Education, Research and Technology (BMBF) and was part of the interdisciplinary project on the dynamic in sulfide and methane biotopes of the Baltic and North Sea (DYSMON).

\section{LITERATURE CITED}

Berner RA (1964) An idealized model of dissolved sulfate distribution in recent sediments. Geochim Cosmochim Acta 28: 1497-1503

Boesen C, Postma D (1988) Pyrite formation in anoxic environments of the Baltic. Am J Sci 288(6):575-603

Brettar I, Rheinheimer G (1991) Denitrification in the Central Baltic: evidence for $\mathrm{H}_{2} \mathrm{~S}$ oxidation as a motor of denitrification at the oxic-anoxic interface. Mar Ecol Prog Ser 77 : $157-169$
Cline JD (1969) Spectrophotometric determination of hydrogen sulfide in natural waters. Limnol Oceanogr 14:454-458

Devol AH (1983) Methane oxidation rates in the anaerobic sediments of Saanich Inlet. Limnol Oceanogr 28:738-742

Duursma EK. Hoede C (1967) Theoretical, experimental and field studies concerning molecular diffusion of radioisotopes in sediments and suspended solid particles of the sea. Part A: Theories and mathematical calculations. Neth J Sea Res 3:423-457

Fossing $H_{1}$ Jørgensen BB (1989) Measurement of bacterial sulfate reduction in sediments: evaluation of a single-step chromium reduction method. Biogeochemistry 8:205-222

Gjerde DT, Schmuckler G, Fritz JS (1980) Anion chromatography with low-conductivity eluents. II. J Chromat 187 $35-45$

Gocke K (1996) Mikrobielle Stoffumsetzungen. In: Rheinheimer G (ed) Meereskunde der Ostsee. Springer-Verlag, Berlin, p 123-130

Griffiths RP, Caldwell BA, Cline JD, Broich WA, Morita RY (1982) Field observations of methane concentrations and oxidation rates in the southeastern Bering Sea. Appl Environ Microbiol 44:435-446

Heyer J (1990) Der Kreislauf des Methans. Akademie-Verlag, Berlin

Heyer J, Berger U, Suckow R (1990) Methanogenesis in different parts of a brackish water ecosystem. Limnologica 20:135-139

Hoehler TM, Alperin MJ, Albert DB, Martens CS (1994) Field and laboratory studies of methane oxidation in an anoxic marine sediment: evidence for a methanogen-sulfate reducer consortium. Global Biogeochem Cycles 8:451-463

Holme NA, Mcintyre A (1984) Methods for the study of marine benthos. IBP Handbook 16, 2nd edn. Blackwell Scientific, Oxford

Ingvorsen K, Brock TD (1982) Electron flow via sulfate reduction and methanogenesis in the anaerobic hypolimnion of Lake Mendota. Limnol Oceanogr 27:559-564

Iversen N, Blackburn TH (1981) Seasonal rates of methane oxidation in anoxic marine sediments. Appl Environ Microbiol 41:1295-1300

Iversen N, Jørgensen BB (1985) Anaerobic methane oxidation rate at the sulfate-methane transition in marine sediments from Kattegat and Skagerrak (Denmark). Limnol Oceanogr 30:944-955

Jørgensen BB (1977) The sulfur cycle of a coastal marine sediment (Limfjorden, Denmark). Limnol Oceanogr 22:814-832

Jørgensen BB (1978) A comparison of methods for the quantification of bacterial sulfate reduction in coastal marine sediments. I. Measurement with radiotracer techniques. Geomicrobiol J 1:11-27

Jørgensen BB, Bak F (1991) Pathways and microbiology of thiosulfate transformations and sulfate reduction in a marine sediment (Kattegat, Denmark). Appl Environ Microbiol 57:847-856

Jørgensen BB, Bang M, Blackburn TH (1990) Anacrobic mineralization in marine sediments from the Baltic Sea-North Sea transition. Mar Ecol Prog Ser 59:39-54

Jørgensen BB, Revsbech NP (1989) Oxygen uptake, bacterial distribution, and carbon-nitrogen-sulfur cycling in sediments from the Baltic Sea-North Sea transition. Ophelia 31:29-49

Kosiur DR, Warford AL (1979) Methane production and oxidation in Santa Barbara Basin sediments. Estuar Coast Mar Sci 8:379-385

Kuivila KM, Murray JW, Devol AH (1990) Methane production in the sulfate-depleted sediments of two marine basins. Geochim Cosmochim Acta 54:403-411 
Lein AY (1983) Biogeochemistry of the anaerobic diagenesis of recent Baltic Sea sediments. In: Hallberg $R$ (ed) Environ Biogeochem Ecol Bull (Stockholm) 35:441-461

Lein AY, Namsaraev BB, Trotsyuk VY, Ivanov MV (1981) Bactenal methanogenesis in holocene sediments of the Baltic Sea. Geomicrobiol J 2:299-315

Lein AY, Vaynshteyn MB, Namsarayev BB, Kashparova YV, Matrosov AG, Bondar VA, Ivanov MV (1982) Biogeochemistry of anaerobic diagenesis of recent Baltic Sea sediments. Geochemistry Int 19:90-103

Lerman A (1979) Geochemical processes. Water and sediment environments. Wiley, New York

Nehring D, Matthäus W, Lass HU, Nausch G, Nagel K (1995) Hydrographisch-chemische Zustandseinschätzung der Ostsee 1994. Meereswissenschaftliche Berichte des Instituts für Ostseeforschung, Warnemünde, No. 9

Niemestö L, Voipio A (1974) Studies on the recent sediments in the Gotland Deep. Merentutkimuslait Havsforskningsinst Skr 238:17-32

Piker L (1995) Dynamik der Sulfatatmung und ihre Bedeutung für die Kohlenstoff-Mineralisierung in Ostsee-Sedimenten. Ber Inst Meeresk 276:1-183

Piker L, Reichardt W (1997) Activities of sulfate reducing bacteria in littoral sediments of the Southern Baltic and possible implications for mercury ecotoxicity. In: Andrusaitis A (ed) Proc 13th Baltic Mar Biol Symp. Inst Aquatic Ecology, Jurmala, p 235-240

Reeburgh WS (1980) Anaerobic methane oxidation: rate depth distributions in Skan Bay sediments. Earth Planet Sci Lett 37:345-352

Reeburgh WS, Heggie DT (1977) Microbial methane consumption reactions and their effect on methane distributions in freshwater and marine environments. Limnol Oceanogr 22:1-9

Reeburgh WS, Ward BB, Whalen SC, Sandbeck KA, Kilpatrick KA, Kerkhof LJ (1991) Black Sea methane geochemistry. Deep Sea Res 38, Suppl 2:S1189-S1210

Rheinheimer G (1996) Meereskunde der Ostsee. SpringerVerlag, Berlin

Editorial responsibility: Tom Fenchel,

Helsinger, Denmark
Sahores JJ, Witherspoon PA (1970) Diffusion of light paraffin hydrocarbons in water from $2^{\circ} \mathrm{C}$ to $80^{\circ} \mathrm{C}$. In: Hodson GD, Speers GC (eds) Advances in organic geochemistry 1966. Pergamon, Oxford, p 219-230

Schmaljohann R (1996) Methane dynamics in the sediment and water column of Kiel Harbour (Baltic Sea). Mar Ecol Prog Ser 131:263-273

Schmaljohann R, Piker L, Imhoff JF (1998) The distribution of methane and hydrogen sulfide in basin sediments of the central and southern Baltic Sea. Meyniana 50 (in press)

Schneider A, Imhoff JF (1996) Role of nitrate in the oxidation of reduced sulfur compounds in sediments of the Baltic Sea. In: Fischer U, Grieshaber MK (eds) Processes and structures in marine methane and sulfide biotopes. Shaker, Aachen, p 87-89

Skyring GW (1987) Sulfate reduction in coastal ecosystems. Geomicrobiol J 5:3-4

Thode-Andersen S, Jørgensen BB (1989) Sulfate reduction and the formation of ${ }^{35} \mathrm{~S}$-labeled $\mathrm{FeS}, \mathrm{FeS}_{2}, \mathrm{~S}^{0}$ in coastal marine sediments. Limnol Oceanogr 34:793-806

Voipio A, Mälkki P (1972) Variations of the vertical stability in the Northern Baltic. Merentutkimuslait Havsforskningsinst $\mathrm{Skr} 237: 3-12$

Ward DM, Winfrey MR (1985) Interactions between methanogenic and sulfate-reducing bacteria in sediments. Adv Aquat Microbiol 3:141-177

Westrich JT, Berner RA (1984) The role of sedimentary organic matter in bacterial sulfate reduction: the $G$ model tested. Limnol Oceanogr 29:236-249

Whiticar MJ (1982) The presence of methane bubbles in the acoustically turbid sediments of Eckernförder Bay, Baltic Sea. In: Manheim FT, Fanning KA (eds) Dynamic environments of the ocean floor. Lexington Books, Lexington, MA, p 219-235

Widdel F (1998) Microbiology and ecology of sulfate- and sulfur-reducing bacteria. In: Zehnder AJB (ed) Biology of anaerobic microorganisms. Wiley \& Sons, New York, p 469-587

Submitted: December 12, 1996; Accepted: August 8, 1997 Proofs received from author(s): November 11, 1997 